\title{
ENERGY BALANCE OF A LOW ENERGY HOUSE
}

\author{
Rasa Džiugaitè-Tumèniené ${ }^{1}$, Vidmantas Jankauskas ${ }^{2}$, Violeta Motuziené $\dot{e}^{3}$ \\ ${ }^{1,2,3}$ Department of Building Energetics, Vilnius Gediminas Technical University, \\ Sauletekio al. 11, LT-10223 Vilnius, Lithuania \\ E-mails: ${ }^{1}$ rdziugaite@yahoo.com (corresponding author); ${ }^{2}$ vidmantas.jankauskas@vgtu.lt; \\ 3violeta.motuziene@vgtu.lt \\ Received 21 Oct. 2011; accepted 26 Jan. 2012
}

\begin{abstract}
Currently, such topics as improvement of energy efficiency of buildings and energy systems, development of sustainable building concepts, and promotion of renewable energy sources are in the focus of attention. The energy efficiency targets of the European Union are based on information regarding energy consumed by buildings. The amount of energy consumed by buildings depends on the main influencing factors (namely, climate parameters, building envelope, energy systems, building operation and maintenance, activities and behaviour of occupants), which have to be considered in order to identify energy efficiency potentials and opportunities.

The article aims to investigate the total amount of energy consumed by a low energy house, built in Lithuania, using a combination of energy consumption data received from a simulation and measured energy consumption data. The energy performance analysis in the low energy house revealed some factors that have the main influence on the total figures of energy consumed by the house. The identified significant factors were used to find the optimal solutions for the design of low energy buildings.
\end{abstract}

Keywords: energy balance, low energy residential house, simulation, measurements.

\section{Introduction}

Buildings account for $40 \%$ of total energy consumption in the European Union (European Parliament and Council 2010). The sector is expanding, which is bound to increase its energy consumption. Therefore, the reduction of energy consumption and greenhouse gas emissions in the buildings sector is a common target in energy and environmental policies in the European Union.

The new generation buildings - namely, a low energy building, a passive house, a nearly zero energy building with a very high energy performance and a significant share of energy supply from renewable energy sources reduce the demand for the operating energy (Engelund Thomsen et al. 2008). However, the reduction of the demand for the operating energy is achieved by increased use of passive and active technologies (Sartori, Hestnes 2007). Passive technologies include increased insulation, better performing windows, reduction of air infiltration losses, and heat recovery from ventilation air. Active technologies include heat pumps coupled with air or ground/water heat sources, solar thermal collectors, solar photovoltaic panels and biomass boilers.

Presently, economic considerations argue against aiming for only energy efficiency in the form of passive technologies (ever-greater insulation, air tightness ant etc.). Hence, attention must also be paid to production of energy on site and to the related need of rationally handle energy allocation in a smart grid (Dieryckx 2010). How- ever, it is important to note that an accurate energy balance of the house should be identified, in order to select the best available technologies for the house.

The purpose of this article is:

- using a combination of energy consumption data received from a simulation and real measurements, to investigate the total energy consumption of a low energy building;

- to identify the factors that have the main influence on the total figures of energy consumed by the house.

This paper describes the existing low energy house, built in Vilnius, presents the simulated and monitored energy performance of the house and discusses the critical factors, which have the main influence to the total energy consumption of the house.

\section{Description of a low energy house}

\subsection{The building envelope}

The low energy house in this study is an existing individual family house with five residents. It is built in Vilnius. The main geographical and climatic data, also some relevant house features are shown in Table 1.

The structural system of the house is a residual formworks system from polystyrene foam blocks. The polystyrene foam blocks are made from hollow blocks, which are tightly interconnected and have formed connections on the connecting surface. During the construc- 
tion works, the inner cavity of hollow blocks was reinforced using reinforcement bars and filled with the fluid mixture of concrete.

Table 1. Main features and climatic data of the house in Vilnius

\begin{tabular}{l|c|c|c}
\hline \multicolumn{2}{|c|}{ Geographical and climatic data } & \multicolumn{2}{|c}{ House features } \\
\hline $\begin{array}{l}\text { Latitude } \\
\text { Longitude }\end{array}$ & $\begin{array}{c}\mathrm{N} 54^{\circ} 41^{\prime} \\
\mathrm{E} 25^{\circ} 19^{\prime}\end{array}$ & $\begin{array}{c}\text { Total floor } \\
\text { area }\end{array}$ & $\begin{array}{c}153.50 \mathrm{~m}^{2} \\
\text { (one } \\
\text { floor })\end{array}$ \\
\hline $\begin{array}{l}\text { Degree days } \\
\left(\theta_{i}=23^{\circ} \mathrm{C}\right)\end{array}$ & Heated area & $153.50 \mathrm{~m}^{2}$ \\
\hline $\begin{array}{l}\text { Average yearly } \\
\text { temperature }\end{array}$ & $6.7^{\circ} \mathrm{C}$ & Total volume & $452.39 \mathrm{~m}^{3}$ \\
\hline $\begin{array}{l}\text { Lowest outdoor } \\
\text { air temperature }\end{array}$ & $-23^{\circ} \mathrm{C}$ & $\begin{array}{c}\text { Orientation of } \\
\text { entrance }\end{array}$ & $\begin{array}{c}\text { North- } \\
\text { East }\end{array}$ \\
\hline \multicolumn{3}{|c}{}
\end{tabular}

The extra insulation of $15 \mathrm{~cm}$ polystyrene foam slabs is mounted on the exterior facades. The windows are with exceptionally low thermal transmittance, triplepane insulated glazing (with a good solar heat-gain coefficient, low-emissivity coatings, argon gas fill, and 'warm edge' insulating glass spacers) with air-seals and specially developed thermally-broken window frames. The thermal transmittance of the house components are shown in Table 2.

Table 2. The thermal transmittance of house elements

\begin{tabular}{|c|c|c|}
\hline $\begin{array}{l}\text { House } \\
\text { component }\end{array}$ & Structure of the component & $\begin{array}{l}\text { Thermal } \\
\text { transmittance } \\
\left(\mathrm{W} / \mathrm{m}^{2} \mathrm{~K}\right)\end{array}$ \\
\hline $\begin{array}{l}\text { External } \\
\text { walls }\end{array}$ & $\begin{array}{l}\text { Stucco, polystyrene foam blocks } \\
\text { EPS100-M30, reinforcement } \\
\text { bars, concrete, polystyrene foam } \\
\text { slabs EPS70-M15, gypsum plas- } \\
\text { ter boards }\end{array}$ & 0.120 \\
\hline Roof & $\begin{array}{l}\text { PVC roofing, cement mortar, } \\
\text { polystyrene foam slabs EPS100- } \\
\text { M20, reinforced concrete slabs } \\
\text { PK24-2 }\end{array}$ & 0.087 \\
\hline Floor & $\begin{array}{l}\text { Three layered laminated board, } \\
\text { cement mortar, polystyrene foam } \\
\text { slabs EPS } 80-M 17 \text {, flashing, con- } \\
\text { crete with gravel and stone rubble } \\
\text { B15 S4 }\end{array}$ & 0.111 \\
\hline Windows & $\begin{array}{l}\text { Plastic frame of } 82 \mathrm{~mm} \text { thickness, } \\
\text { with } 6 \text { cells, triple-pane insulated } \\
\text { glazing, solar heat gain coeffi- } \\
\text { cient of the windows (SHGC) is } \\
0.52\end{array}$ & 0.802 \\
\hline $\begin{array}{l}\text { External } \\
\text { door }\end{array}$ & $\begin{array}{l}\text { Plastic frame of } 82 \mathrm{~mm} \text { thickness, } \\
\text { with } 6 \text { cells, triple-pane insulated } \\
\text { glazing }\end{array}$ & 1.20 \\
\hline \multicolumn{2}{|c|}{$\begin{array}{l}\text { Linear thermal transmittance of thermal bridge } \\
(\mathrm{W} / \mathrm{mK}) \text { : }\end{array}$} & \\
\hline \multicolumn{2}{|c|}{ outside corner } & -0.114 \\
\hline \multicolumn{2}{|l|}{ roof } & -0.095 \\
\hline \multicolumn{2}{|c|}{ floor slab } & -0.153 \\
\hline \multicolumn{2}{|c|}{ window } & 0.035 \\
\hline
\end{tabular}

As can be seen from Table 2, the super insulation is used to significantly reduce the heat transfer through the walls, roof and floor compared to standard residential houses. The house was studied using the pressurization test. The results have shown that the actual measured airtightness of the house construction is $0.6 \mathrm{~h}^{-1}$ at $50 \mathrm{~Pa}$, resulting in approximately $0.05 \mathrm{~h}^{-1}$ external air infiltration rate under normal conditions.

\subsection{Space heating and ventilation}

The existing low energy house is mechanically ventilated during the entire day. A heat recovery ventilation system with a heat recovery rate of $83 \%$ (according to technical data of the Producer) and high-efficiency electronically commutated motors (ECM) are used to maintain air quality. Specific fan power (SFP) is $1.5 \mathrm{~kW} /\left(\mathrm{m}^{3} / \mathrm{s}\right)$. Since the house is essentially airtight, the rate of air change is $0.400 \mathrm{~h}^{-1}\left(\mathrm{~L}_{\text {supply }}=\mathrm{L}_{\text {exhaust }}=150 \mathrm{~m}^{3} / \mathrm{h}, \mathrm{t}_{\text {ext }}=-23^{\circ} \mathrm{C}, \mathrm{t}_{\text {int }}=\right.$ $21^{\circ} \mathrm{C}$ ). All ventilation ducts are insulated and sealed against air leakage.

Heat for space heating is produced by the air-towater heat pump. The energy system of the low energy house is shown in Fig. 1.

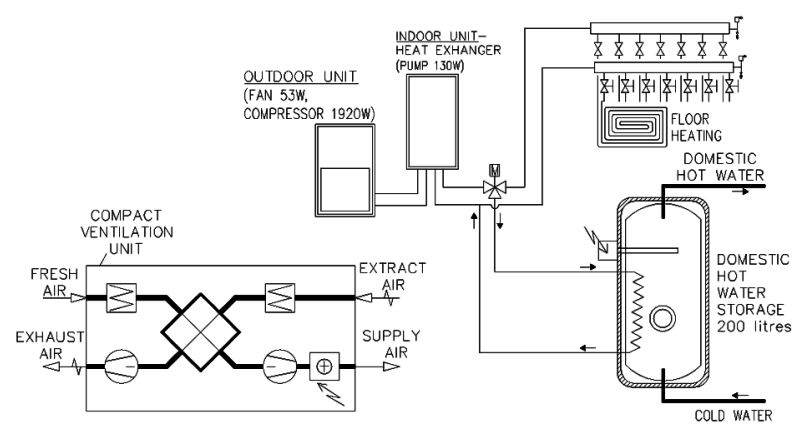

Fig. 1. Energy system of the low energy house in Vilnius

As can be seen from Fig. 1, the main components of the house energy system are: the air-to-water heat pump, the hot water storage tank (200l) with integrated back-up electric heater, and a ventilation unit. The underfloor heating system is installed in the living room and kitchen, and the radiators are installed in bedrooms.

\subsection{Domestic hot water supply}

Domestic hot water is prepared by the air-to-water heat pump. In case, when outdoor air temperature decreases below $-15{ }^{\circ} \mathrm{C}$, the back-up electric heater, integrated into the hot water storage tank (200l), covers the remaining domestic hot water demand.

\section{Methods}

This paper presents the energy balance of the low energy house, which is split into the heat balance at the building level and the energy balance at the system level. The house energy needs for heating are calculated on the basis of the heat balance of the house and are the input for the energy balance of the heating and ventilation systems. Three different types of calculation methods were used to evaluate the heat balance at the building level and the energy balance at the level of the building service systems. The flowchart of the evaluation of the house heat and energy balance is shown in Fig. 2 . 


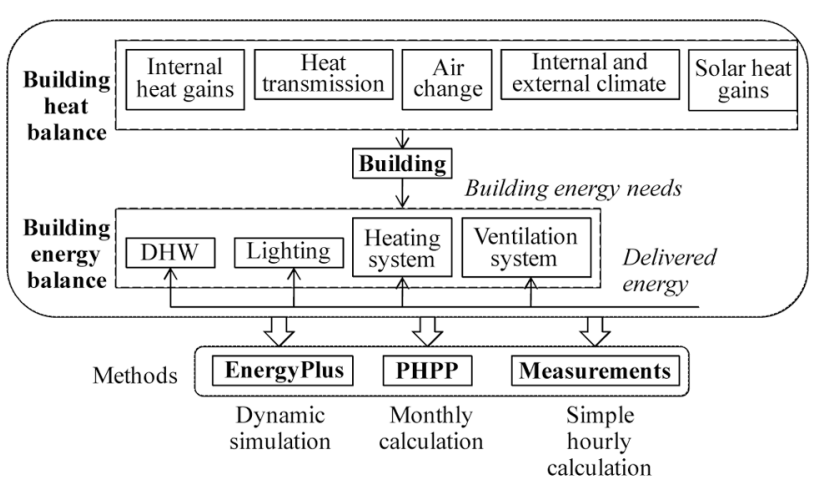

Fig. 2. Flowchart of evaluation of house heat and energy balance

The detailed descriptions of the quasi-steady-state calculation, simple hourly dynamic calculation and dynamic simulation methods are given in LST EN ISO 13790 (2008). The results given in this paper are based on using:

- EnergyPlus simulation software as detailed dynamic simulation method;

- Passive House Planning Package (PHPP) as monthly quasi-steady-state calculation method;

- measurements, which were used applying the simple hourly dynamic calculation method.

\subsection{Simulation model}

A simulation of the energy performance of the existing low energy house was carried out using DesignBuilder simulation software. This software provides a range of environmental performance data such as: energy consumption, internal comfort data and HVAC component sizes. Output is based on detailed sub-hourly simulation time steps using the EnergyPlus dynamic thermal simulation engine. Therefore, a model of the low energy house was made using the DesignBuilder interface for the EnergyPlus simulation engine.

The EnergyPlus weather file from the ASHRAE International Weather for Energy Calculations (IWEC) data for Kaunas (LTU-Kaunas-IWEC) was used for the simulation of the energy performance of the existing low energy house (IWEC source data 2001).
The geometrical simulation model of the house, created with DesignBuilder, is shown in Fig. 3.

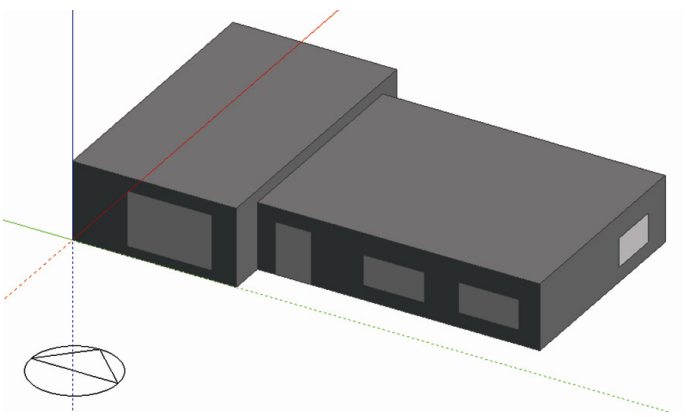

Fig. 3. The geometrical model of the house

Two types of zones were distinguished: livingdining room and bedrooms. Each zone has its own typical operation schedule and indoor parameters.

\subsection{Measurements}

The actual performance of the house was monitored from 2 October 2010 to 30 April 2011. The main parameters (outdoor and indoor air temperatures, relative humidity, solar radiation, indoor air pollution) were measured. The measured data is the basis for the results presented in this paper.

\subsection{Calculations with PHPP}

The results of measured and simulation data were compared with the data, obtained using Passive House Planning Package (PHPP). PHPP calculates energy demand for high-performance houses. It is compatible with international standard LST EN ISO 13790 (Feist 2007). The entire house was treated as one zone for energy calculation. The monthly energy balances were used in the calculation.

\subsection{Input data}

The main input data, used for simulation and calculations, is presented in Table 3 .

Table 3. The input data for simulation and calculations

\begin{tabular}{l|c|c|c}
\hline \multicolumn{1}{c|}{ Main parameters } & Measured data & EnergyPlus & PHPP \\
\hline \multicolumn{1}{c|}{ Geometry of the house } & \multicolumn{2}{|c}{ According to the drawings of house technical design } \\
\hline \multicolumn{1}{c|}{ Thermal properties of materials (see Table 2) } \\
\hline Air change $\left(\mathrm{h}^{-1}\right)$ & $\begin{array}{c}\text { Sub-hourly measurements of } \\
\text { outdoor air temperature }\left({ }^{\circ} \mathrm{C}\right) \text { and } \\
\text { relative humidity }(\%)\end{array}$ & $\begin{array}{c}\text { EnergyPlus weather file from } \\
\text { the ASHRAE IWEC data } \\
\text { for Kaunas }\end{array}$ & $\begin{array}{c}\text { Monthly climate data for Vilnius, } \\
\text { entered in PHPP calculation } \\
\text { spreadsheet }\end{array}$ \\
\hline External infiltration $\left(\mathrm{h}^{-1}\right)$ & $\begin{array}{c}0.400 \text { (measured) } \\
\text { air-tightness of house) }\end{array}$ & 0.400 & 0.400 \\
\hline $\begin{array}{l}\text { Set-point temperature for } \\
\text { heating }\left({ }^{\circ} \mathrm{C}\right)\end{array}$ & $\begin{array}{c}\text { Sub-hourly measurements of indoor } \\
\text { air temperature }\left({ }^{\circ} \mathrm{C}\right) \text { and relative } \\
\text { humidity }(\%) \text { for separate zones }\end{array}$ & $\begin{array}{c}23 \text { (assumed according to } \\
\text { the real measured data) }\end{array}$ & $\begin{array}{c}23 \text { (assumed according to the } \\
\text { real measured data) }\end{array}$ \\
\hline $\begin{array}{l}\text { Set-point temperature for } \\
\text { ventilation }\left({ }^{\circ} \mathrm{C}\right)\end{array}$ & $\begin{array}{c}\text { Sub-hourly measurements of supplied } \\
\text { and extracted air temperatures }\left({ }^{\circ} \mathrm{C}\right) \\
\text { and relative humidity }(\%)\end{array}$ & $\begin{array}{c}21 \text { (assumed according to } \\
\text { the real measured data) }\end{array}$ & $\begin{array}{c}21 \text { (assumed according to the } \\
\text { real measured data) }\end{array}$ \\
\hline $\begin{array}{l}\text { Internal heat gains from } \\
\text { occupants }\left(\mathrm{W} / \mathrm{m}^{2}\right)\end{array}$ & $\begin{array}{c}0.60 \text { (according to data modelled } \\
\text { with EnergyPlus) }\end{array}$ & $\begin{array}{c}\text { According to occupancy } \\
\text { schedules for separate zones, } \\
\left.0.033 \text { (people/m }{ }^{2}\right)\end{array}$ & $\begin{array}{c}0.60 \text { (according to data mod- } \\
\text { elled with EnergyPlus) }\end{array}$ \\
\hline
\end{tabular}


End of Table 3

\begin{tabular}{|c|c|c|c|}
\hline Main parameters & Measured data & EnergyPlus & PHPP \\
\hline \multicolumn{4}{|c|}{ Internal heat gains from appliances $\left(\mathrm{W} / \mathrm{m}^{2}\right)$ are not evaluated } \\
\hline External heat gains & $\begin{array}{l}\text { Sub-hourly measurements of } \\
\text { solar radiation }\left(\mathrm{W} / \mathrm{m}^{2}\right)\end{array}$ & $\begin{array}{c}\text { EnergyPlus weather file } \\
\text { from the ASHRAE IWEC } \\
\text { data for Kaunas }\end{array}$ & $\begin{array}{l}\text { Annual values of average global } \\
\text { radiation for Vilnius, entered in } \\
\text { PHPP }\left(\mathrm{kWh} / \mathrm{m}^{2} \mathrm{a}\right)\end{array}$ \\
\hline $\begin{array}{l}\text { Energy efficiency of ventila- } \\
\text { tion system }(\%)\end{array}$ & 93.3 (measured average value) & $\begin{array}{c}93.3 \text { (measured average } \\
\text { value) }\end{array}$ & 93.3 (measured average value) \\
\hline $\begin{array}{l}\text { Degree days }(\mathrm{kKh} / \mathrm{heating} \\
\text { season })\left(\theta_{i}=23^{\circ} \mathrm{C}\right)\end{array}$ & $\begin{array}{l}116.1 \text { (according to real } \\
\text { measured data) }\end{array}$ & $\begin{array}{l}111.8 \text { (calculated according } \\
\text { to IWEC data base (2010)) }\end{array}$ & $\begin{array}{c}114.5 \text { (calculated according to } \\
\text { RSN 156-94 (1995) data) }\end{array}$ \\
\hline $\begin{array}{l}\text { Degree days }(\mathrm{kKh} / \text { heating } \\
\text { season })\left(\theta_{i}=17^{\circ} \mathrm{C}\right)\end{array}$ & 101.6 & 81.2 & 84.0 \\
\hline $\begin{array}{l}\text { Degree days }(\mathrm{kKh} / \text { heating } \\
\text { season })\left(\theta_{i}=12^{\circ} \mathrm{C}\right)\end{array}$ & 88.9 & 55.8 & 58.6 \\
\hline
\end{tabular}

The measured data of the studied house was used as the basis for the main boundary conditions (air change, external infiltration, set-point temperatures for heating and ventilation, energy efficiency of ventilation system), used in calculations and simulation.

The results of energy performance of the studied house were received using the different data of outdoor climate, which is given in RSN 156-94 (1995) and ASHRAE International Weather for Energy Calculations. The validation of the use of RSN 156-94 (1995) and IWEC source data (2010) in the energy calculations was analysed by Motuziene (2010). The results of the analysis showed that the coincidence of temperatures for all months is good. According to the results of the analysis, the outdoor climate, presented in PHPP and EnergyPlus, was assumed as comparable.

In order to ascertain the error, which can occur due to the different climate data, the energy calculations were made with PHPP, using the average monthly external temperatures from EnergyPlus. The difference between the calculated heat demand values, using climate data of RSN 156-94 (1995) and IWEC source (2010), is 2.2\%.

\subsection{Energy balance of the house}

The energy balance of the monitored house was defined by Eq. (1):

$$
\begin{aligned}
& Q_{H, f}=\left[\left(\sum A_{i} \cdot U_{i}+\sum l_{k} \cdot \Psi_{k}+c \rho \sum V_{j} \cdot n_{j}\right) \cdot \psi_{\theta(t)} \cdot\right. \\
& \left.\left(\theta_{i, f}-\theta_{e, f}\right) \cdot z_{f}\right]-\left[\Psi_{P} \cdot\left(Q_{P, e x t}+Q_{P, \text { int }}\right)+Q_{A E I}+(1)\right. \\
& \left.\sum \psi_{R, k} \cdot Q_{N R, k}-\sum Q_{N f, k}\right],
\end{aligned}
$$

where: $Q_{H, f}$ is an actual energy demand $(\mathrm{kWh} /$ heating season); $A_{i}$ is an area of each part of the building envelope $\left(\mathrm{m}^{2}\right) ; U_{i}$ is a heat transfer coefficient of the building envelope part $\left(\mathrm{W} /\left(\mathrm{m}^{2} \cdot \mathrm{K}\right)\right) ; l_{k}$ is a length of linear thermal bridge $(\mathrm{m}) ; \Psi_{k}$ is a linear thermal transmittance of thermal bridge $(\mathrm{W} / \mathrm{m} \cdot \mathrm{K}) ; c$ is a specific heat of air $(\mathrm{Wh} /(\mathrm{kg} \cdot \mathrm{K})) ; \rho$ is a density of air $\left(\mathrm{kg} / \mathrm{m}^{3}\right) ; V_{j}$ is a house volume $\left(\mathrm{m}^{3}\right) ; n_{j}$ is an air change rate $\left(\mathrm{h}^{-1}\right) ; \psi_{\theta(t)}$ is a factor of indoor temperature reduction; $\theta_{i, f}$ is an actual indoor air temperature $\left({ }^{\circ} \mathrm{C}\right) ; \theta_{e, f}$ is an actual outdoor air temperature $\left({ }^{\circ} \mathrm{C}\right) ; z_{f}$ is an actual length of heating period (h); $\psi_{P}$ is a factor of useful use of heat from solar and internal gains; $Q_{P, \text { ext }}$ are the solar heat gains over the given period $(\mathrm{kWh}) ; Q_{P, \text { int }}$ are the internal heat gains over the given period $(\mathrm{kWh}) ; Q_{A E I}$ is the use of renewable energy sources $(\mathrm{kWh}) ;\left(\psi_{R, k} \cdot Q_{N R, k}\right)$ is a factor of heat recovery from the equipment of k system $(\mathrm{kWh}) ; Q_{N f, k}$ are the actual system losses $(\mathrm{kWh})$.

The actual energy demand was compared with the data of simulations and results of PHPP calculations. In order to compare the results properly, the actual energy demand was normalised, i.e. recalculated according to the standard conditions, when indoor and outdoor air temperatures are defined by the local regulations RSN 156-94 (1995):

$$
\sum Q_{H, n}=\sum Q_{H, f} \cdot \frac{\left(\theta_{i, n}-\theta_{e, n}\right) \cdot z_{n}}{\left(\theta_{i, f}-\theta_{e, f}\right) \cdot z_{f}},
$$

where: $Q_{H, n}$ is a normalised energy demand $(\mathrm{kWh} /$ heating season); $\theta_{i, n}$ is a standard indoor air temperature $\left({ }^{\circ} \mathrm{C}\right) ; \theta_{e, n}$ is a standard outdoor air temperature $\left({ }^{\circ} \mathrm{C}\right) ; z_{n}$ is standard length of a heating period $(\mathrm{h})$.

\section{Results}

In this section, simulation results are compared to measured data of the house, thereby validating the house simulation model for the parametric studies.

\subsection{Validation of the simulation model}

In order to make sure that the essential characteristics of the house and its energy system are adequately represented in the model and the thermal properties of the house can be simulated with sufficient accuracy, the model was validated with measured data from 2 October 2010 to 30 April 2011. The measured and weighted indoor air temperatures and measured outdoor air temperatures are shown in Fig. 4.

As can be seen from Fig. 4, when outdoor air temperature is lower than $0{ }^{\circ} \mathrm{C}$, the indoor air temperature varies from $21{ }^{\circ} \mathrm{C}$ to $23{ }^{\circ} \mathrm{C}$. However, when outdoor temperature is higher than $0{ }^{\circ} \mathrm{C}$, the space is overheated. The indoor air temperature is up to $24^{\circ} \mathrm{C}$, or even up to $25^{\circ} \mathrm{C}$. 


\subsection{Heat balance of the house}

The heat balance of the monitored house for the heating period was performed using EnergyPlus simulation tool, PHPP calculation tool and the actual data of measurements. The results are shown in Fig. 5.

As can be seen from Fig. 5, the measured normalised annual heat demand value for space heating is $13.1 \%$ lower compared with the value, calculated using PHPP tool and $19.4 \%$ higher compared with the simulated value. In order to clarify the differences between predicted and monitored values of the house heat balance, the main output data is shown in Table 4.

As can be seen from Table 4, the main differences between predicted and monitored values of the house heat balance are due to:

- the set-point temperature for space heating. The measurements have shown that the actual indoor air temperature varies from $21^{\circ} \mathrm{C}$ to $25^{\circ} \mathrm{C}$. Therefore, this value of indoor air temperature is higher than the design value. The same results from the monitoring of Swedish energy-efficient terrace houses have been achieved. The choice of $23{ }^{\circ} \mathrm{C}$ as indoor temperature, instead of $20^{\circ} \mathrm{C}$, has the highest impact; an increase of the space heating demand has been $4.9 \mathrm{kWh} / \mathrm{m}^{2} \mathrm{a}$ (Wall 2006);

- the main reason of the significant fluctuation of the measured temperature is the poor control of the installed heating system of the house;

- the solar heat gains. The simulated solar heat gains are more precise, because of the dynamic evaluation of external shading factors;

- the air-tightness of the building envelope. The value of the modelled external infiltration is very low, when dynamic wind speed evaluation is used. The actual measured constant n50-value has been used in the PHPP calculations and evaluation of measurement data;

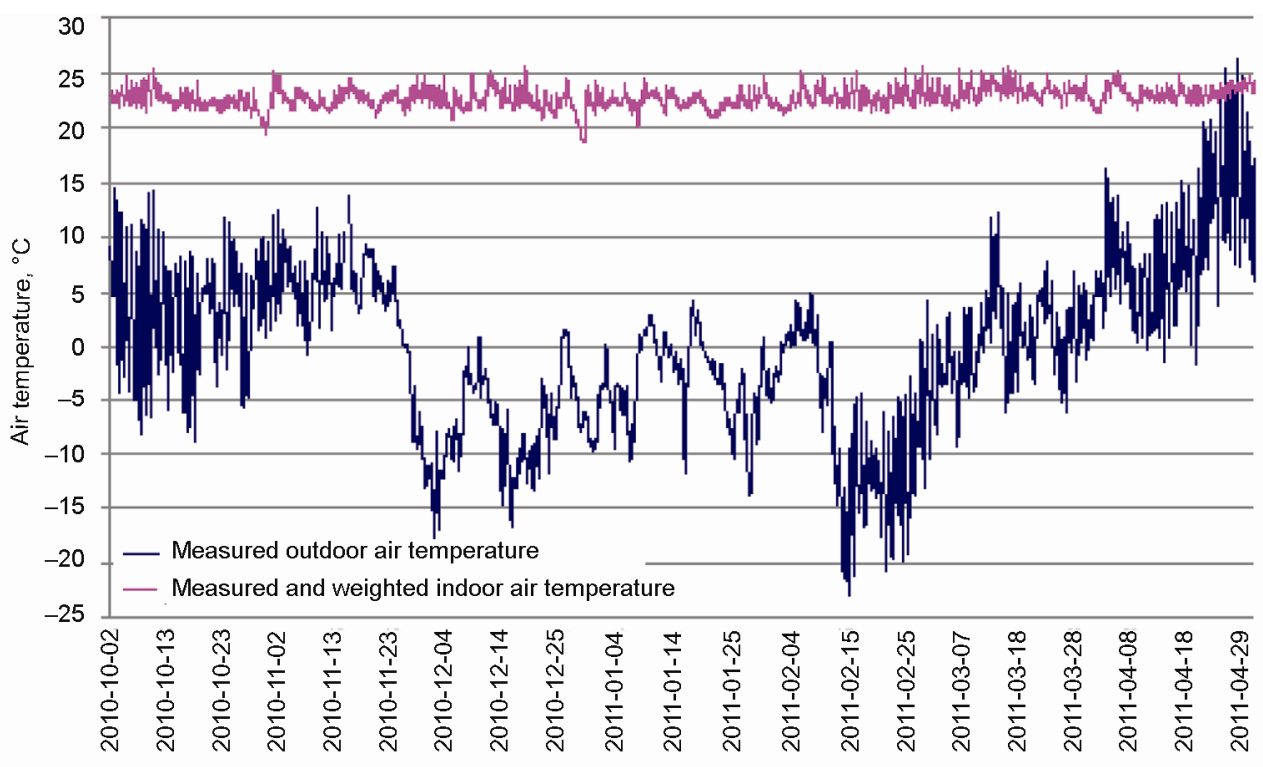

Fig. 4. Measurements data

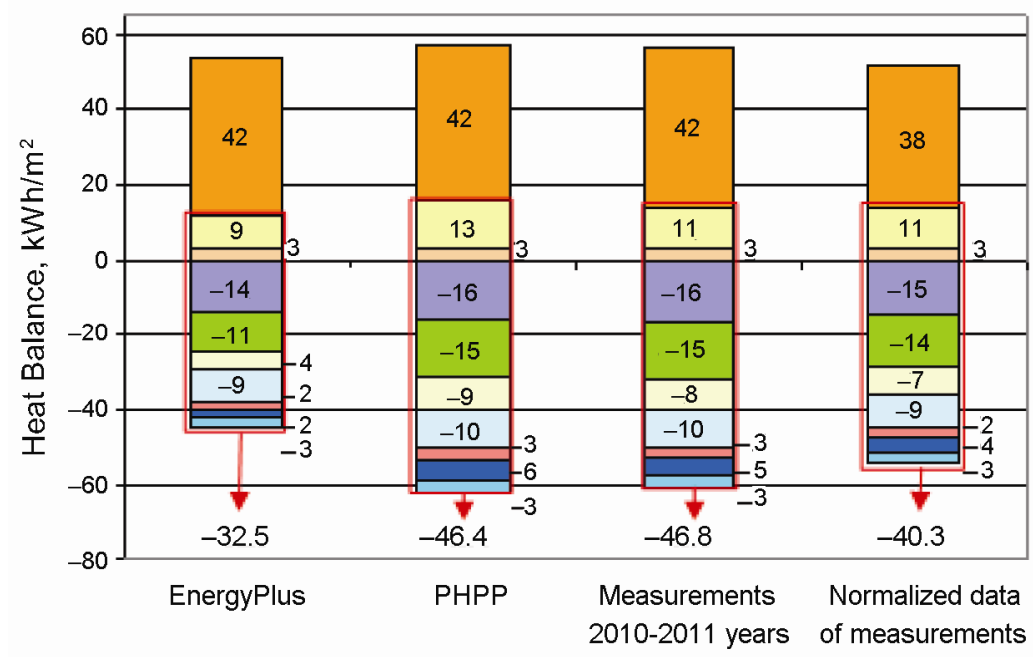

$\square \quad$ Mech. Ventilation Air Heating

$\square$ Heat Recovery

$\square$ Solar Gains

$\square$ Occuparcy

$\square \quad$ External Infiltration

$\square \quad$ External doors

- Exterior Thermal Bridges

$\square$ Roofs

$\square$ Ground Floors

$\square$ Walls

$\square \quad$ Glazing

Fig. 5. Annual heat balance of the low energy house 
Table 4. The output data of simulation and calculations

\begin{tabular}{l|c|c|c}
\hline \multicolumn{1}{c|}{ Output data } & $\begin{array}{c}\text { Normalised } \\
\text { measured data }\end{array}$ & $\begin{array}{c}\text { Ener- } \\
\text { gyPlus }\end{array}$ & PHPP \\
\hline $\begin{array}{l}\text { Outdoor air tem- } \\
\text { perature }\left({ }^{\circ} \mathrm{C}\right)\end{array}$ & $\begin{array}{c}\text { See Fig. } 4 \\
\text { (measured } \\
\text { values) }\end{array}$ & $\begin{array}{c}\text { Simulated } \\
\text { values }\end{array}$ & $\begin{array}{c}\text { Monthly } \\
\text { average } \\
\text { values }\end{array}$ \\
\hline $\begin{array}{l}\text { Indoor air temper- } \\
\text { ature }\left({ }^{\circ} \mathrm{C}\right)\end{array}$ & 23 & 23 & 23 \\
\hline $\begin{array}{l}\text { Transmission heat } \\
\text { transfer } \\
\left(\mathrm{kWh} / \mathrm{m}^{2} \mathrm{a}\right)\end{array}$ & 51.7 & 41.9 & 59.0 \\
\hline $\begin{array}{l}\text { Ventilation heat } \\
\text { transfer by me- } \\
\text { chanical ventila- } \\
\text { tion system } \\
\left(\mathrm{kWh} / \mathrm{m}^{2} \mathrm{a}\right)\end{array}$ & 2.95 & 2.98 & 2.98 \\
\hline $\begin{array}{l}\text { Internal heat gains } \\
\text { from persons } \\
\left(\mathrm{kWh} / \mathrm{m}^{2} \mathrm{a}\right)\end{array}$ & 3.10 & 3.10 & 3.10 \\
\hline $\begin{array}{l}\text { Solar heat gains } \\
\left(\mathrm{kWh} / \mathrm{m}^{2} \mathrm{a}\right)\end{array}$ & 11.30 & 9.30 & 12.6 \\
\hline $\begin{array}{l}\text { Recovered venti- } \\
\text { lation heat losses } \\
\left(\mathrm{kWh} / \mathrm{m}^{2} \mathrm{a}\right)\end{array}$ & 37.5 & 41.6 & 41.6 \\
\hline $\begin{array}{l}\text { Annual heat de- } \\
\text { mand }\left(\mathrm{kWh} / \mathrm{m}^{2} \mathrm{a}\right)\end{array}$ & 40.3 & 32.5 & 46.4 \\
\hline
\end{tabular}

- the heat transfer by transmission to the ground. The simulated value is very low compared with the calculated value. It is due to the different values of the ground temperatures;

- the recovered ventilation heat losses, which depend on the effective heat recovery efficiency. The measurements have shown the higher efficiency of the heat recovery unit;

- the internal heat gains from occupants. The simulated internal heat gains from occupants were based on the occupancy schedule, which was made for separate zones (living-dining room and bedrooms). For the PHPP and measurement data the internal heat gains from occupants was assumed to be the same, because more precise results can be achieved. However, the constant rated value of $1.5 \mathrm{~W} / \mathrm{m}^{2}$ is used according to NS 3033, when the simulation tool is not used during the design stage.

The comparison of the results from PHPP calculation and EnergyPlus simulation has shown the main factors, such as average indoor design temperature, airtightness of the building envelope, external and internal heat sources, efficiency of ventilation system, which influence the final results. However, obtained close to realistic results have proven that use of the EnergyPlus simulation tool or the PHPP calculation tool can help designers making parametric studies and finding optimal solution for the low energy house or a passive house.

The passive house standard requires that the space heating demand should not exceed $15 \mathrm{kWh} / \mathrm{m}^{2}$ (Feist 2007). As can be seen from the results, the monitored house cannot fulfil this requirement. However, it meets the requirements for the low energy house (STR 2.01.09: 2005 2011; NS 3700:2010).

\subsection{Energy balance of the house}

The energy balance of the monitored house for the heating period was performed using the EnergyPlus simulation tool, the PHPP calculation tool and the actual data of measurements. The results are shown in Fig. 6.

As can be seen from Fig. 6, the delivered energy (DE) demand and the non-renewable primary energy (PE) demand for space heating, domestic hot water preparation, pumps and fans of ventilation system are presented. An average value of the primary energy factor for electricity is $2.35 \mathrm{kWh} P \mathrm{PE} / \mathrm{kWh} h_{\mathrm{END}}$. This primary energy factor is based on experience from 17 European countries and used in the calculations. The calculations of delivered energy and primary energy do not include household electricity, because it was not monitored and this factor can vary, depending on the behaviour of occupants.

The monitored non-renewable primary energy demand for space heating, DHW and electricity for mechanical systems is $110 \mathrm{kWh} \mathrm{PE}_{\mathrm{PE}} / \mathrm{m}^{2}$ during a heating period. It means that the monitored house fulfils the requirements for the low energy house (STR 2.01.09:2005 2011; NS 3700:2010).

According to the measured data from 2 October 2010 to 30 April 2011, the actual seasonal coefficient of performance (SCOP) of the air-to-water heat pump amounted to 1.56 . The back-up electric heater, integrated into the hot water storage tank, required $1.4 \%$ of the total delivery energy. The actual SCOP of the air-to-water heat pump was taken for the calculation of the delivery energy demand.

As can be seen from Fig. 6, the measured normalised value of delivered energy is $16 \%$ lower compared with the value, calculated using PHPP tool and 5.5\% higher compared with the simulated value. This difference between the predicted values and measured value appears due to the evaluation of energy demand for electricity for mechanical systems (pumps and fans).

The energy balance of the monitored house showed that potential energy savings can be achieved by optimising the house energy system.

\section{Parametric studies}

The parametric studies are presented to carry out the main critical factors for designing well-performing houses and to illustrate their impact on the space heating demand and peak load. The parametric studies for the different cases of the houses were made using the EnergyPlus simulation tool. The data obtained after simulations were processed with MS Excel.

\subsection{The main critical factors}

The main critical factors, which are related to the characteristics of the building envelope and energy system, are:

-a heat transfer coefficient of the walls $\left(U_{\text {walls }}, \mathrm{W} / \mathrm{m}^{2} \mathrm{~K}\right)$;

-a heat transfer coefficient of the windows $\left(U_{\text {win }}, \mathrm{W} / \mathrm{m}^{2} \mathrm{~K}\right)$;

-a solar heat gain coefficient of the windows (SHGC); 
- a heat transfer coefficient of the roof $\left(U_{\text {roof }}, \mathrm{W} / \mathrm{m}^{2} \mathrm{~K}\right)$;

- a heat transfer coefficient of the floor $\left(U_{f l o o r}, \mathrm{~W} / \mathrm{m}^{2} \mathrm{~K}\right)$;

- a percentage of the glazed surface area of the house (\%Win), which was chosen considering the recommendations for the most energy efficient window-to-wall ratios (Motuziene, Juodis 2010);

- an orientation of the house (Orien);

- an external air infiltration rate under normal conditions (Ext_Inf);

-a seasonal coefficient of performance (SCOP) of the house energy system;

- a set-point temperature for space heating $\left(\theta_{i},{ }^{\circ} \mathrm{C}\right)$;

- an efficiency of heat recovery unit $\left(\eta_{\text {rec }}, \%\right)$.

The monitored house was chosen as a template for simulations. The house geometry, ventilation system, and occupancy schedule remained the same. Each factor was defined according to four levels of the houses (STR 2.01.09:2005 2011). The high levels of the houses fulfil the requirements for low energy and passive houses (STR 2.01.09:2005 2011; NS 3700:2010). The values of the main critical factors are presented in Table 5.
Table 5. Values of the main critical factors

\begin{tabular}{c|c|c|c|c}
\hline \multirow{2}{*}{ Factor } & \multicolumn{4}{|c}{ House level } \\
\cline { 2 - 5 } & Very high & High & Medium & Standard \\
\hline $\mathrm{U}_{\text {walls }}$ & 0.086 & 0.120 & 0.130 & 0.194 \\
\hline $\mathrm{U}_{\text {win }}$ & 0.745 & 0.802 & 1.256 & 1.512 \\
\hline $\mathrm{SHGC}$ & 0.351 & 0.477 & 0.579 & 0.649 \\
\hline $\mathrm{U}_{\text {roof }}$ & 0.07 & 0.087 & 0.114 & 0.132 \\
\hline $\mathrm{U}_{\text {floor }}$ & 0.093 & 0.111 & 0.145 & 0.177 \\
\hline \%Win & 14 & 16 & 25 & 40 \\
\hline Orien & $\mathrm{N} / \mathrm{S}$ & $\mathrm{N} / \mathrm{S}$ & $\mathrm{NE} / \mathrm{SW}$ & $\mathrm{E} / \mathrm{W}$ \\
\hline Ext_Inf & 0.05 & 0.05 & 0.08 & 0.20 \\
\hline $\mathrm{SCOP}$ & 3 & 2.5 & 1.75 & 1 \\
\hline$\theta_{\mathrm{i}}$ & 21 & 21 & 21 & 21 \\
\hline$\eta_{\text {rec }}$ & 83 & 83 & 83 & 83 \\
\hline & & & &
\end{tabular}

Four different simulations with the EnergyPlus software were performed in order to illustrate the impact of the main critical factors.

\subsection{Energy performance of the houses}

The energy simulations showed that the main differences between predicted and monitored energy performance concern the space heating demand. Therefore, the heat balance for different levels of houses was carried out. The results of the simulation are shown in Fig. 7.

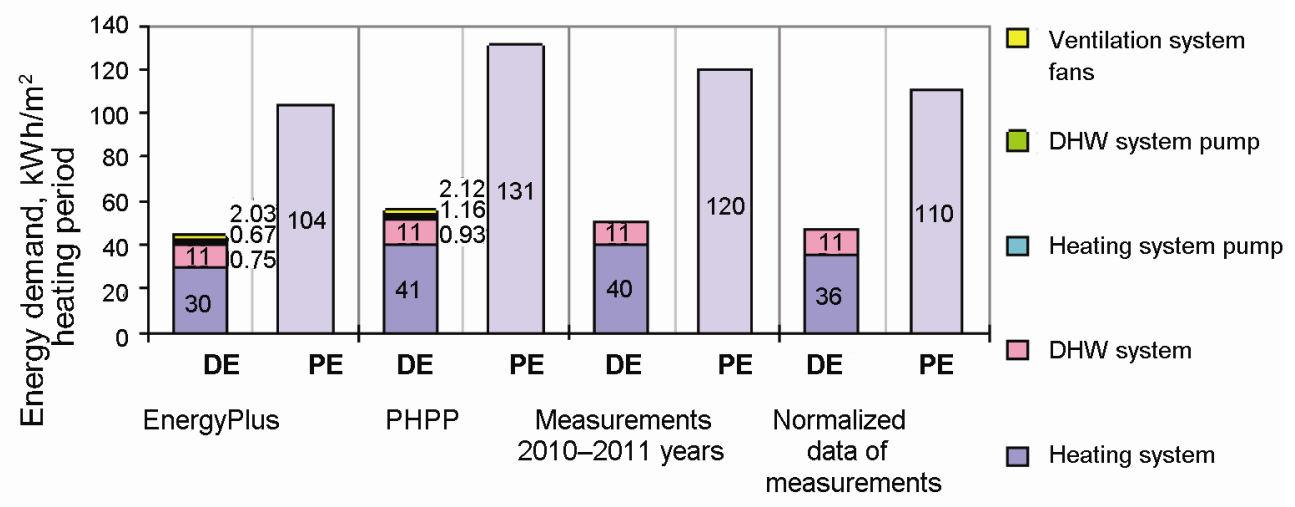

Fig. 6. Energy demand of the low energy house for heating period

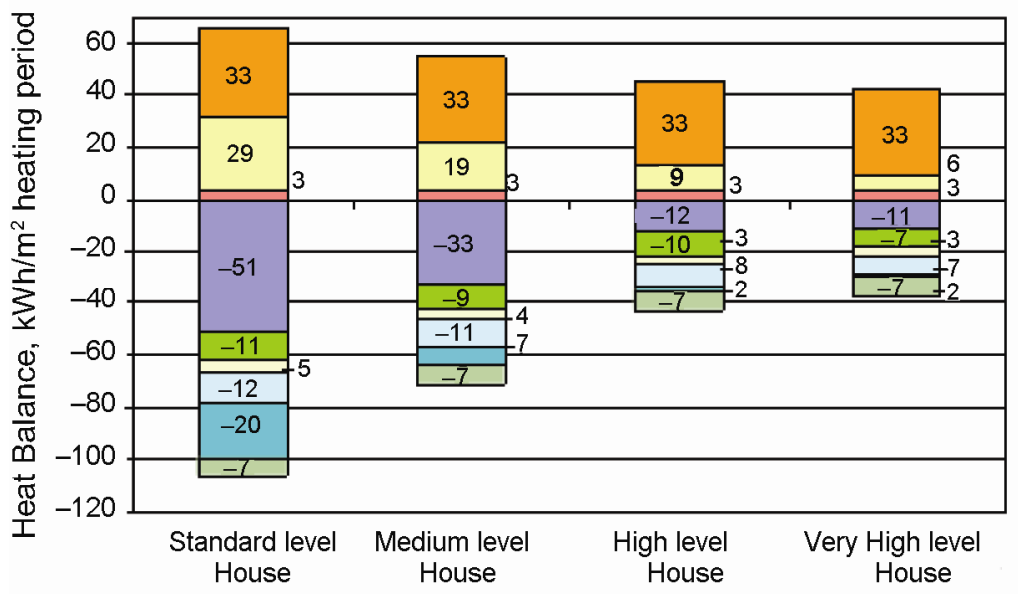

Fig. 7. Heat balance of the different types of houses

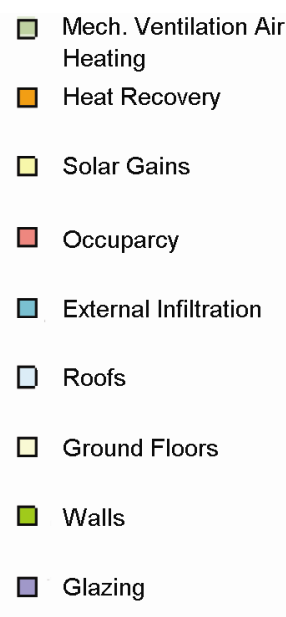

Fig. 7. Heat balance of the different ty 
As can be seen from Fig. 7, the improved values of heat transfer coefficients of the house elements, the reduction of the glazed surface area and improved airtightness of the building envelope cause the significantly lower heat demand for space heating compared with the standard house, i.e. $62 \%$. Though, $46 \%$ better solar heat gain coefficients of windows cause $77 \%$ smaller solar heat gains. It is important to note that using a larger window area facing south and higher value of the solar heat gain coefficient would necessitate an increased ventilation rate and use of shading devices to reduce excessive temperatures, or increase the power needed for cooling during the summer (Persson et al. 2006).

In Fig. 8, the simulated space heating demand and peak load for each level of the houses are shown.

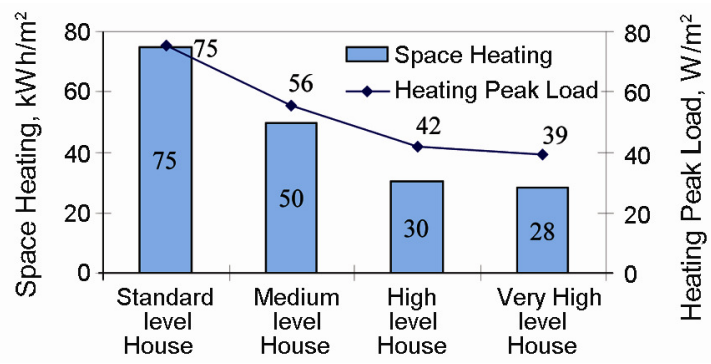

Fig. 8. The change in peak load and space heating demand for the different types of houses

As can be seen from Fig. 8, the heating peak loads of the high level houses are reduced by approx. $48 \%$ compared with the standard house, resulting to $48 \%$ lower heating power of the building energy system.

In Fig. 9, the influence of ventilation heat recovery on space heating demand is shown.

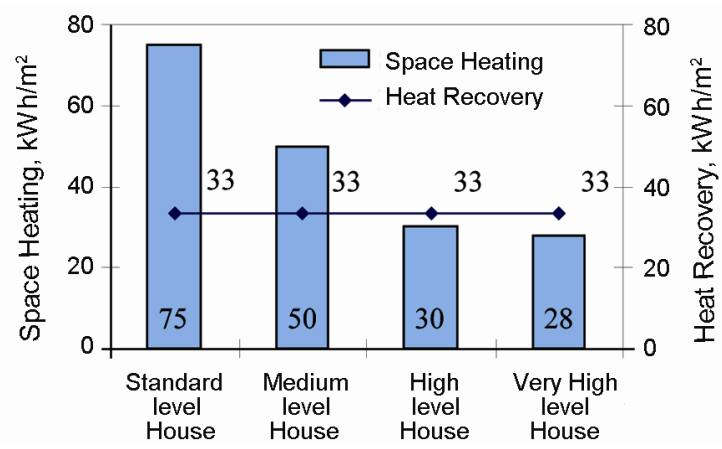

Fig. 9. The influence of ventilation heat recovery on space heating demand

As can be seen from Fig. 9, the ventilation heat recovery is very important for the houses with a high tightness envelope. The ventilation heat recovery causes $54 \%$ of energy savings in the heat balance of the house.

In Fig. 10, the influence of heat gains on space heating demand is shown.

As can be seen from Fig. 10, the total heat gains have a great contribution to the heat balance of the standard and medium levels houses. The total heat gains could cause $43 \%$ energy savings in the energy balance of houses. The high value of solar heat gain coefficient of win- dows increases the value of solar heat gains. Therefore, low solar heat gain coefficients of windows could prevent from overheating of rooms in summer time. The internal heat gains remain the same in all cases.

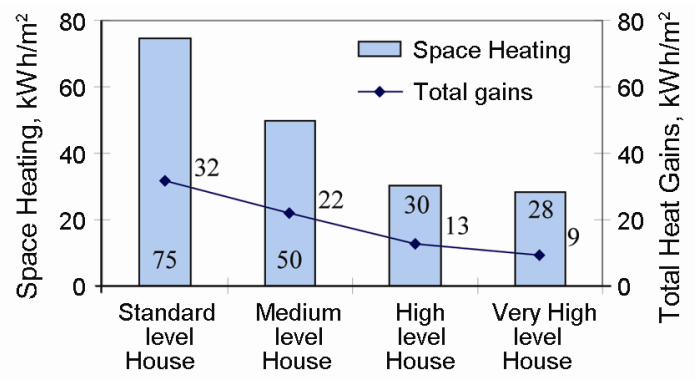

Fig. 10. The influence of heat gains on space heating demand

The house of very high level requires $28 \mathrm{kWh} / \mathrm{m}^{2}$ for space heating. However, if there would be no solar radiation and occupancy, the space heating demand would increase up to $37 \mathrm{kWh} / \mathrm{m}^{2}$.

In Fig. 11, the simulated space heating demand and delivered energy for each level of the houses are shown.

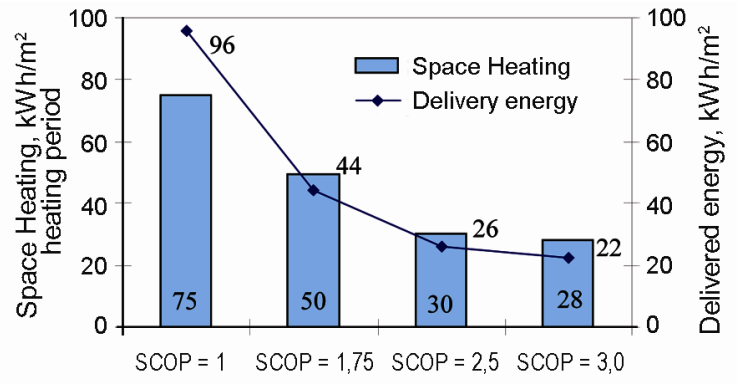

Fig. 11. The change in space heating demand and delivered energy for the different types of houses

As can be seen from Fig. 11, the efficiency of the house energy system has the greatest impact on the delivered energy for space heating, DHW preparation and electricity for mechanical systems. Thus, during the design stage of the house, an extreme attention has to be given to the energy system and its overall energy efficiency.

The reduction of total delivered energy in the high level houses compared with normal medium house is approximately $50 \%$. The similar results were received in energy-efficient terrace houses in Sweden (Wall 2006).

The presented parametric studies showed the main critical factors for designing well-performing houses and illustrated their impact on the heat and energy balances of houses. However, future works will be carried out using the method for multiple criteria analysis of the low energy houses, in order to make a rational decision at the micro, meso and macro environment levels (Kaklauskas et al. 2011).

\section{Conclusions}

1. The measured normalised annual heat demand value for space heating is $13.1 \%$ lower compared with the 
value, calculated using the PHPP tool and $19.4 \%$ higher compared with the value, simulated by the EnergyPlus. Therefore, during the design stage, the EnergyPlus simulation software should be used carefully, as too optimistic values are obtained due to dynamic evaluation of external infiltration.

2. The monitored non-renewable primary energy demand for space heating, domestic hot water, fans and pumps is $110 \mathrm{kWh} / \mathrm{m}^{2}$ heating season, which complies with the requirements for the low energy house.

3 . The measurements show that the indoor air temperature varied from $21{ }^{\circ} \mathrm{C}$ to $25^{\circ} \mathrm{C}$. The main reason of high indoor air temperature is inefficient control of the heating system. Therefore, the measured delivered energy demand is $47 \mathrm{kWh} / \mathrm{m}^{2}$.

4. The measurements show that the efficiency of the heat exchanger of the ventilation system is $93.3 \%$, which is higher than the designed value of $83 \%$.

5. The simulations show that internal heat gains from persons are $60 \%$ lower, when the occupancy schedule is used. Thus, occupancy behaviour should be studied during the design stage of the low energy house.

6. The parametric studies have demonstrated that:

- the improved values of heat transfer coefficients of the house elements, the reduction of the glazed surface area and better air-tightness of the building envelope cause $62 \%$ lower heat demand for space heating compared with the standard house;

- the ventilation heat recovery causes $54 \%$ of energy savings in the energy balance of the house;

- the efficiency of the house energy system has the greatest impact on the total delivered energy.

\section{References}

Dieryckx, M. 2010. Sustainable energy use related to efficient heating and cooling systems - A manufacturer's view, Rehva European HVAC Journal 47(4): 20-25.

Engelund Thomsen, K.; Wittchen, K. B.; EuroACE. 2008. European national strategies to move towards very low energy buildings. Aalborg: SBi, Statens Byggeforskningsinstitut. $33 \mathrm{p}$.

European Parliament and Council 2010. Directive 2010/31/EU of the European Parliament and of the Council of 19 May 2010 on the energy performance of buildings, Official Journal of the European Union L153: 13-35.
Feist, W. 2007. PHPP: far more than just an energy calculation tool. [Online] Passive Building Institute, Darmstadt [accessed 17 June 2011]. Available from Internet:

http://www.passivhaustagung.de/Passive_Building_E/PH PP.html

IWEC source data 2001. International Weather for Energy Calculations (IWEC). [Online] American Society of Heating, Refrigerating and Air-Conditioning Engineers (ASHRAE), Atlanta [accessed 20 April 2011]. Available from Internet: http://apps1.eere.energy.gov/buildings/ energyplus/weatherdata sources.cfm\#IWEC

Kaklauskas, A.; Rute, J.; Gudauskas, R.; Banaitis, A. 2011. Integrated model and system for passive buildings multiple criteria analysis, International Journal of Strategic Property Management 15(1): 74-90. http://dx.doi.org/10.3846/1648715X.2011.574903

LST EN ISO 13790:2008 Energy performance of buildings Calculation of energy use for space heating and cooling. Lithuanian department for standardization. Vilnius, 2008. $160 \mathrm{p}$.

Motuzienè, V. 2010. Complex analysis of the influence of glazing on energy demand of public buildings. $\mathrm{PhD}$ thesis. Vilnius: Vilnius Gediminas Technical University. http://dx.doi.org/10.3846/jcem.2010.39

Motuziene, V.; Juodis, E. S. 2010. Simulation based complex energy assessment of office building fenestration, Journal of Civil Engineering and Management 16(3): 345-351.

NS 3700:2010 Kriterier for passivhus og lavenergihus Boligbygninger [Criteria for passive buildings and low energy buildings - Residential buildings]. Norge: Standard Norges komité, 2010. 20 p.

Persson, M. L.; Roos, A.; Wall, M. 2006. Influence of window size on the energy balance of low energy buildings, Energy and Buildings 38(3): 181-188. http://dx.doi.org/10.1016/j.enbuild.2005.05.006

RSN 156-94 Statybine klimatologija [Climatology of construction]. Vilnius: Lithuanian Ministry of Construction and Urban Development, 1995. 136 p.

Sartori, I.; Hestnes, A. G. 2007. Energy use in the life cycle of conventional and low-energy buildings, Energy and Buildings 39(3): 249-257. http://dx.doi.org/10.1016/j.enbuild.2006.07.001

STR 2.01.09:2005 Pastatu energinis naudingumas. Energinio naudingumo sertifikavimas [Energy performance of buildings. Energy performance certification]. Vilnius: Lithuanian Ministry of Environment, 2011. 42 p.

Wall, M. 2006. Energy-efficient terrace buildings in Sweden. Simulations and measurements, Energy and Buildings 38(6): 627-634.

http://dx.doi.org/10.1016/j.enbuild.2005.10.005

Rasa DŽIUGAITE்-TUMĖNIENĖ. PhD student of Energetics and Thermal Engineering (since 2009), MSc in Energetics (2006), BA in Energetics (2004), Vilnius Gediminas Technical University. Publications: the author of 2 research papers. Research interests: energy efficiency in buildings, integration of renewable energy sources into the energy systems, energy simulations.

Vidmantas JANKAUSKAS. Professor at the Department of Building Energetics (since 2009), Vilnius Gediminas Technical University. Publications: the author of 1 course book and over 50 research papers. Research interests: economics of energy, economy and regulation of monopoly. Membership: International Association of Energetics Economists.

Violeta MOTUZIENE். Associated Professor at the Department of Building Energetics (since 2010), Vilnius Gediminas Technical University. Publications: the author of 11 research papers. Research interests: energy efficiency in buildings, integrated building design, energy simulations. 